\title{
I Conferência dos Secretários de Fazenda para a Reforma Tributária
}

$\mathrm{R}$ EALZARAM-SE no $10^{\circ}$ andar do Ministério da Fazenda em ras da manhã, as sessões de abertura e de debates em tôrno do anteprojeto de código tributário nacional, tendo ficado o início dos trabalhos, sob a presidência do Ministro da Fazenda, Economista e Professor OCTAvio GouvÊA"DE BuLHốES.

Deu origem a êsse conclave a determinaçáo contida na Emenda Constitucional $\mathrm{n}^{\circ} 18$, de 1-12-1965, que se refere à lei complementar que será baixada para regular o sistema tributário nacional.

Outrossim, vemo-lo em consonância com o que dispõe a alinea $b$, inciso XV do art. $5^{\circ}$ da Constituição, sôbre normas gerais de direito financeiro, relativas à matéria tributária de competência da União, dos Estados, do Distrito Federal e Municipios, sem prejuizo da legislação complementar existente. Para regulamentar o que ai ficou estipulado, em legislação única, a isso atinente, é que está sendo levantado o estudo do presente Código.

A Comissão de Reforma do Ministério da Fazenda presidida pelo Sr. Dr. Luiz Simões Lopes, após haver feito meticulcso estudo sôbre o assunto, elaborou a Parte I do citado Códigc.

$\mathrm{O}$ aludido congresso teve a presença de representantes de diversos estados de nossa Federação, que expuseram teses concretas sôbre a matéria. Decidiu-se êle pela criação de um Fundo de Participação dos Estados, que será distribuido, proporcionalmente, à respectiva população e ao inverso da renda per capita de cada Estado. Em face dêsse critério, após os debates, foram estabelecidos os coeficientes de participação de cada Estado aqui apresentados, na parte final dêsse registro.

Damos, a seguir, o roteiro integral do trabalho cumprido pelos congressistas, além do Livro Primeiro do anteprojeto do citado Código Tributário Nacional. 


\section{PROGRAMA DE TRABALHO}

REUNIÃO DE SECRETÁRIOS DE FAZENDA DOS ESTADOS

15 a 17 de junho de 1966

Dia 15 - Quarta-feira

$10.00 \mathrm{~h}$ - Sessão solene de abertura sob a presidência do Ministro da Fazenda.

Local: Auditório do Ministério da Fazenda (13ªndar).

Agenda:

1 - Discurso de abertura pelo Ministro da Fazenda, Dr. Octavio Gouvêa de Bulhões.

2 - Discurso de um representante dos Secretários de Fazenda.

3 - Discurso de um representante das Confederaçôes de Classe.

4 - Encerramento da Sessão pelo Sr. Ministro da Fazenda.

14.30 h - Tema: Anteprojeto de Lei Complementar da Emenda Constitucional $n^{\circ} 18$ (Livro Primeiro do Código Tributário Nacional).

Local: Salão Nobre do Ministério da Fazenda ( $10^{\circ}$ andar).

Agenda:

1 - Exposição introdutória pelos Drs. Gérson Augusto da Silva e Gilberto de Ulhoa Canto.

2 - Breve apresentação das Emendas sugeridas peĩas diversas representações.

3 - Abertura dos debates pela ordem dos capitulos e artigos do Anteprojeto.

4 - Formação de uma Comissão incumbida da ccordenação das Emendas. (Comissão I). Local e horário de trabalho.

\section{Dia 16 - Quinta-feira} $10.00 \mathrm{~h}$ - Tema: Anteprojeto (modêlo) do Impôsto sôbre Circulação de
Mercadorias.

Local: Salăo Nobre (10\% andar).

Agenda:

1 - Exposição introdutória do Dr. Gerson Augusto da Silva.

2 - Abertura dos debates sôbre o Anteprojeto (rarte normativa).

3 - Formação de uma Comissão incumbida de coordenar as emẽndas ao Anteprojeto. (Comissão II). Local e horário de trabalho.

$14.30 \mathrm{~h}$ - Tema:

1 - Determinação da aliquota do Impôsto sôbre Circulação.

2 - Regulamentação do Fundo de Participação dos Estados.

Local: Salão Nobre (10* andar).

Agenda:

1 - Exposição introdutória pelo Dr. Gerson Augusto da Silva.

2 - Abertura dos debates sôbre o Tema 1.

3 - Formação de uma Comissão incumbida da redação das Conclusões sôbre o Tema 1 (Comissão III). Local $\mathrm{e}$ horário dos trabalhos. 
4 - Exame da contribuição dos Secretários de Fazenda para a re. gulamentação do Fundo de Participação dos Estadios.

5 - Formação de uma Comissão incumbida de coordenar as proposições sôbre o Tema 2 (Comissão IV), Local e horário de trabalho.

17.00 h - Tema: Anteprojeto de Normas Gerais de Direito Tributário (Livro Segundo do Código Tributário Nacional).

Local: Salão Nobre (10 andar $)$.

Agenda:

1 - Exposição do Dr. Gilberto de Ulhoa Canto.

2 - Abertura dos debates.

3 - Encerramento.

\section{Dia 17 - Sexta-feira}

$10.00 \mathrm{~h}$ - Tema:

1 - Emendas ao Anteprojeto de Lei Complementar (Livro Primeiro do Código Tributário Nacional),

2 - Emendas ao Anteprojeto modêlo do Impôsto sôbre Circulação (Plarte normativa).

Local: Salão Nobre (10 andar).

Agenda:

1 - Apresentação das conclusões sôbre o Tema 1 pelo Coordenador da Comissão I.

2 - Discussão e aprovação.

3 - Apresentação das conclusões sôbre o Tema 2 pelo Coordenador da Comissão II.

4 - Discussão e aprovação.

$14.30 \mathrm{~h}-$ Tema:

1 - Determinação da aliquota do Impôsto sôbre Circulação.

2 - Fundo de Participação dos Estados.

Local: Salăo Nobre.

Agenda:

1 - Apresentação das conclusões sôbre ○ Tema 1 pelo Coordenador da Comissão III.

2 - Discussão e aprovação.

3 - Apresentação das conclusões sôbre o Tema 2 pelo Coo:denador da Comissão IV.

4 - Discussão e aprovação.

$17.00 \mathrm{~h}$ - Sessão solene de encerramento dos Trabalhos da Reunião.

Local: Auditório do Ministério da Fazenda (13 andar).

Agenda:

1 - Abertura da Sessão pelo Ministro da Fazenda, Dr. Octavio

2 - Apreciação das conclusões gerais dos Fazenda.

3 - Discurso de encerramento pelo Ministro do Planejamento e Coordenação Econômica - Dr. Roberto Campos. 


\section{ANTEPROJETO \\ CÓDIGO TRIBUTÃRIO NACIONAL}

\section{DISPOSIÇÕES PRELIMINARES}

Art. 1\% Este Código, em seu Livro Primeiro, regula, com fundamento na Emenda Constitucional $\mathrm{n}^{\circ} 18$, de $1^{\circ}$ de dezembro de 1965 , o sistema tri butário nacional e estatui a lei complementar a que essa Emenda se refere na alínea "c" do inciso IV do art. $2^{\circ}$, no art. $4^{\circ}$, nos $\$ \S 2^{\circ}$ e $4^{\circ}$ do art. $9^{\circ}$, nos $\S \S 1^{\circ}$ e $2^{\circ}$ do art. 12, no parágrafo único do art. 15; e, em seu Livro Segundo, determina, com fundamento na alinea " $b$ " do inciso XV do art. $5^{\circ}$ da Constituição, as normas gerais de direito financeiro, relativas à matéria tribu. tária, aplicáveis à União, aos Estados, ao Distrito Federal e aos Municipios, sem prejuizo da respectiva legislação complementar, supletiva ou regulamentar.

LIVRO PRIMEIRO

\section{SISTEMA TRIBUTÅRIO NACIONAL}

\section{Título I}

DISPOSIÇÕES GERAIS

Art. 2\% O sistema tributário nacional é regido pelo disposto na Emenda Constitucional $n^{2} 18$, de $1^{\circ}$ de dezembro de 1965, em leis complementares, em resolução do Senado Federal e, nos limites das respectivas competências, em leis federais, nas Constituições e nas leis estaduais e em leis municipais.

Art. $3^{\circ}$ Tributo é tôda prestação pecuniária compulsória que não constitua sanção de ato ilicito, instituido em lei pela União, pelos Estados, pelo Distrito Federal ou pelos Municipios, no uso de competência constitucional inerenţe à sua condição de pessoa juridica de direito público, e cobrada mediante atividade administrativa plenamente vincuiada.

Art. 4, A natureza juridica especifica de cada tributo determina-se pelo fato gerador da respectiva obrigação, sendo irrelevantes para quaiificá-las:

I - a denominação e demais características formais adotadas pela le que o tenha instituido;

II - a destinação legal do produto da sua arrecadação.

Art. $5^{\circ}$ Os tributos são impostos, taxas e contribuições de melhoria.

\section{TíTULO II}

\section{COMPETENCIA TRIBUTARIA}

\section{CAPÍtulo I}

\section{DISPOSIÇŌES GERAIS}

Art. 6? A atribuição constitucional de competência tributária compreende a competência legislativa plena, ressalvadas as limitações contidas na Constituição Federal, observado o disposto neste Código, nas Constituições dos Estados e nas Leis Orgânicas do Distrito Federal e dos Municipios.

Parágrafo único. Os tributos cuja arrecadação seja distribuida no todo ou em parte a outras pessoas jurídicas de direito público pertencem a competência legislativa daquela a que tenham sido atribuidos pela Constituição Federal ou pelas Constituições dos Estados. 
Art. $7^{\circ}$ A competência tributária é indelegável, salvo atribuição das funções de arrecadar ou fiscalizar tributos, ou de executar leis, serviços, atos ou decisões administrativas em matéria tributária, conferida por uma pessoa juridica de direito público a outra, nos têrmos do $\S 3^{\circ}$ do art. 18 da Constituição.

$\S 1^{\text {. A }}$ atribuição compreende as garantias e os privilégios processuais que competem à pessoa juridica de direito público que a conterir.

$\S 2^{\circ}$ A atribuição pode ser revogada a qualquer tempo, por ato unilateral da pessoa juridica de direito público que a tenha efetuado.

$\S 3^{\circ}$ Não constitui delegação o cometimento a pessoas de direito privado, do cncargo ou da função de arrecadar tributos.

Art. $8^{\circ} \mathrm{O}$ não-exercicio da competência tributária não a defere a țessoa juridica de direito público diversa daquela a que a Constituição a tenha atribuido.

\section{CAPÍTULO II}

\section{LIMITAÇOES DA COMPETENCIA TRIBUTÁRIA}

\section{Seçãoo I - Disposições Gerais} nicipios:

Art. 9 $9^{\circ}$ E vedado à União, aos Estados, ao Distrito Federal e aos Mu-

I - instituir ou majorar tributo sem que a lei o estabeleça, ressalvado, quanto à majoração, o disposto no art. 22 , no art. 27 e no $\S 2^{\circ}$ do art. 61 ;

II - cobrar impôsto sôbre o patrimônio e a renda com base em lei posterior à data inicial do exercício financeiro a que corresponda;

III - estabelecer limitações ao tráfego, no território nacional, de pessoas ou mercadorias, por meio de tributos interestaduais ou intermunicipais;

IV - cobrar impôsto sôbre:

a) o patrimônio, a renda ou os serviços uns dos outros;

b) templos de qualquer culto;

c) o patrimônio, a renda ou serviços de partidos politicos e de institui. ções de educação ou de assistência social, observados os requisitos fixados na Seção II dêste Capitulo; livros.

d) papel destinado exclusivamente à impressão de jornajs, periódicos e

$\S 1^{\text {Q }} \mathrm{O}$ disposto no inciso IV não exclui a atribuição, por lei, às entidades nêle referidas, da condição de responsável pelos tributos que lhes caiba arrecadar na fonte, e não as dispensa da prática de atos, previstos em lei, assecuratórios do cumprimento de obrigações tributárias por terceiros.

$\S 2^{\circ}$ O disposto na alinea "a" do inciso IV aplica-se, exclusivamente, aos serviços próprios das pessoas juridicas de direito público a que se refere êste artigo, e inerentes aos seus objetivos.

Art. 10. E vedado à Uniăo instituir tributo que não seja uniforme em todo o território nacional, ou que importe distinção ou preferência em favor de determinado Estado ou Município.

Art. 11. E vedado aos Estados, ao Distrito Federal e aos Municípios estabelecer diferença tributária entre bens de qualquer natureza, em razão de sua procedência ou do seu destino. 


\section{Seção II - Disposições Especiais}

Art. 12. O disposto na alinea "a" do inciso IV do art. $9^{\circ}$, observado o disposto no $\S 1^{\circ}$ dêsse artigo, é extensivo às autarquias criadas pela União, pelos Estados, pelo Distrito Federal ou pelos Municipios, tão-sòmente no que se refere ao patrimônio, à renda ou aos serviços vinculados às finalidades essenciais. ou delas decorrentes.

Art. 13. O disposto na alinea "a" do inciso IV do art. 9", dêste Cón digo, não é extensivo aos serviços públicos concedidos, cujo tráamento tributário é estabelecido pelo poder concedente no que se refere aos tributos de sua competência, ressalvados os serviços públicos federais concedidos, cuja isenção geral de tributos pode ser instituida pela União, por meio de leł especial e tendo em vista o interêsse comum, observado, nesse caso. o disposto no $\& 1^{\circ}$, do referido art. $9^{\circ}$.

Parágrafo único. As leis especiais a que se refere êste artigo, vigentes à data da promulgação dêste Código, permanecem em vigor enquuanto não revogadas ou alteradas por outras.

Art. 14. O disposto na alinea " $\mathrm{c}$ " do inciso IV do art. $9^{\circ}$ é subor. dinado à observância dos seguintes requisitos pelas entidades nêle referidas:

I - não distribuirem a seus dirigentes ou associados qualquer parcela de seu patrimônio ou de suas rendas, por qualquer título que possa representar rendimento, ganho ou lucro para os respectivos beneficiários;

II - aplicarem integralmente os seus recursos na manutenção e no desenvolvimento dos objetivos sociais;

III - manterem escrituração de suas receitas e despesas en: livros revestidos das formalidades capazes de assegurar sua exatidão.

$\S 1^{\circ}$ Na falta de cumprimento do disposto-neste artigo, ou no $\S 1^{\circ}$ do art. $9^{\circ}$, a lei pode suspender a aplicação do beneficio.

$\S 2^{\circ}$ Os serviços a que se refere a alinea " $c$ " do inciso IV do art. 9" são, exclusivamente, os diretamente relacionados com os objetivos sociais das entidades de que trata êste artigo, previstos nos respectivos estatutos ou atos constitutivos.

Art. 15. Sòmente a União pode instituir empréstimos compulsórios, nos seguintes casos excepcionais:

I - guerra externa, ou sua iminência;

II - calamidade pública que exija auxilio federal impossivel de atender com os recursos orçamentários disponiveis;

III - ocorrência de circunstâncias que exijam a absorção temporária de poder aquisitivo.

Parágrafo único. O empréstimo compulsório será instituido por lei, que fixará obrigatòriamente o prazo e as condiçôes do respectivo resgate e observará, no que fôr aplicável, o disposto neste Códig̣o.

TíruLo III

\section{IMPOSTOS}

\section{CAPÍTULO I}

\section{DISPOSIÇOEES GERAIS}

Art. 16. Impôsto é o tributo cuja obrigação tem por fato gerador uma situação independente de qualquer atividade estatal especifica, relativa ao
contribuinte.

Art. 17. Os impostos componentes do sistema tributário nacional são exclusivamente os que constam dêste Título, com as competências e limitaçōes
nêles previstas. 


\section{Art. 18. Compete:}

I - à União instituir, nos Territórios Federais, os impostos atribuidos aos Estados, e, se aquêles não forem divididos em Município, cumulativamente os atribuidos a êstes.

II - ao Distrito Federal e aos Estados não divididos em Municípios, instituir, cumulativamente, os impostos atribuidos aos Estados e aos Municipios.

\section{CAPÍTULO II}

\section{IMPOSTOS SOBRE O COMERCIO EXTERIOR}

\section{Seção I - Impôsto sôbre a Importaçăo}

Art. 19. O impôsto, de competência da União, sôbre a importação de produtos estrangeiros, tem como fato gerador a entrada dêstes no território nacional.

\section{Art. 20. A base de cálculo do impôsto é:}

I - quando a aliquota seja especifica, ıqualquer unidade de medida, pertencente ao sistema métrico decimal, que seja adotada pela lei tributária.

II - quando a aliquota seja ad valorem, o preço normal do produto, assim entendido o que êle, ou produto similar, alcançaria èn una venda, em condições de livre concorrência, entre vendedor e comprador independentes, para entrega no pôrto ou lugar de entrada do produto no país;

III - quando se trata de produto apreendido ou abandonado, levado a leilão, o preço da respectiva arrematação.

Art. 21. Para os efeitos do artigo anterior, entende-se por venda em condições de livre concorrência, entre vendedor e comprador independentes, aquela em que concorrem os seguintes elementos:

I - a única prestação a cargo do comprador é o pagamento do preço;

II - o preço é fixado independentemente de relaçôes ccmerciais, financeiras, ou de outra natureza, contratuais ou não, além des criadas pela própria venda, entre, de um lado, o vendedor ou pessoa a êle associada e, de outro lado, o comprador ou pessoa a êle associada;

III - nenhuma impotância decorrente da ulterior revenda, cessão, ou utilização do produto vendido retorna, direta ou indiretamente, ao vendedor ou à pessoa a êle associada.

Parágrafo único. Para os efeitos dêste artigo, entendem-se duas pessoas como associadas quando uma delas tem interêsse em quaisquer bens ou ne. gócios da outra, ou quando ambas têm interêsses comuns em qualquer bem ou negócios, ou, ainda, quando uma terceira pessoa tem simultâneamente in. terêsses em quaisquer bens ou negócios de cada uma delas, sejam êsses in. terêsses diretos ou indiretos.

Art. 22. O Poder Executivo pode, nas condições e nos limites estabelecidos em lei, alterar as aliquotas ou as bases de cálculo do impôsto, a fim de ajustá-lo aos objetivos da politica cambial e do comércio exterior.

\section{Art. 23. Contribuinte do impôsto é:}

I - tôda pessoa que, tendo interêsse na entrada do produto no território nacional, pratique, direta ou indiretamente, ato tendente a promovê-la, sem prejuizo da responsabilidade tributária e penal do agente material;

II - o arrematante dos produtos apreendidos ou abandonados. 


\section{Seção II - Impôsto sôbre a Exporfação}

Art. 24. O impôsto, de competência da União, sôbre a exportação para o estrangeiro, de produtos nacionais ou nacionalizados, tem como fato gerador a saida dêstes do território nacional.

\section{$\S 1^{\circ}$ Consideram-se nacionais:}

I - os produtos naturais, obtidos no pais, exportados em sua condição original;

II - os produtos industriais fabricados no pais, ainda que, total ou parcialmente, ccm matéria-prima ou componentes estianıeiros;

III - os produtos, naturais ou industriais, de procedência estrangeira, que tenham sido submetidos, no pais, a qualquer operação que lhes modifique a natureza ou a finalidade, ou os aperfeiçoe para o consumo.

$\$ 2^{\circ}$ Consideram-se nacionalizados os prudutos, naturais ou industriais, de procedência estrangeira, exportados na mesma condição em que entraram no país, ainda que com diferente embalagem, envoltório, acondicionamento denominação, marca, ou outra caracteristica extrinseca.

Art. 25. A base de cálculo do impôsto é:

I - quando a aliquota seja especifica, qualquer unidade de medida, per. tencente ao sistema métrico decimal, que sej̣a adotada pela lei tributária;

II - quando a aliquota seja ad valorem, o preço ou o valor da operação de que decorra a saida do produto, os quais não serão inferiores à cotação média do produto nos principais mercados importadores, deduzidas as despesas de transporte e seguro, ou, na falta da referida cotação, ao preço normal da optração, na forma do disposto no inciso II do art. 20 , combinado com o art. 21 e seu parágrafo único.

Parágrafo único. $\mathrm{Na}$ determinação da base de cálculo, considera-se a entrega como efetuada no pôrto ou lugar da saída do produto, deduzidos os tributos diretamente incidentes sôbre a operação de expurtação, e, nas vendas efetuadas a prazo superior aos correntes no mercado internacional, o custo do financiamento.

Art. 26. A lei pode adotar como base de cálculo a parcela do valo: ou do preço, referidos no artigo anterior, excedente de valor básico fixado de acôrdo com os critérios e dentro dos limites po: ela estabelecidos.

Art. 27. O Poder Executivo pode, nas condições e nos limites estabelecidos em lei, alterar as aliquotas ou as bases de cálculo do impôsto a fim de ajustá-lo aos objetivos da politica cambial e do comércio exterior:

Art. 28. Contribuinte do impôsto é tôda pessoa qua, tendo interêsse na saida do produto do território nacional, pratique, direta ou indiretamente, ato tendente a promovê-la, sem prejuizo da responsabilidade tributária e peral do agente material.

Art. 29. A receita liquida do impôsto destina-se à formação de reservas monetárias, na forma da lei.

\section{CAPÍTULO III}

\section{IMPOSTO SOBRE O PATRIMONIO E A RENDA}

\section{Seção I - Impôsto sôbre a Propriedade Territorial Rural}

Art. 30. O impôsto, de competência da União, sôbre a propriedade territorial rural, tem como fato gerador a propriedade, o dominio útil, uu a justa posse do imóvel destinado à exploração agricola, pecuária, agroindustrial ou extrativa. 
Art. 31. A base de cálculo do impôsto é o valor fundiário do imóvel, declarado pelo contribuinte e não impugnado pela Fazenda Nacional ou resultante de avaliação cadastral.

Art. 32. Contribuinte do impôsto é o proprietário do imóvel, o títular do seu dominio útil, ou o seu possuidor a justo titulo.

\section{Seção II - Impôsto sôbre a Ptopriedade Predial e Teritorial Llrbana}

Art. 33. O impôsto, de competência dos Municipios, sôbre a propriedade predial e territorial urbana, tem como fato gerador a propriedade, o dominio útil, ou a justa posse de bem imóvel por natureza, como céfinido na lei civil, construído ou não, localizado nas áreas urbanas dos Municipios.

Art. 34. A base do cálculo do impôsto é o valor venal do imóvel, determinado, na forma da lei, por qualquer dos seguintes critérios, isoladamente ou combinados: Municipal;

I - declaração do contribuinte, não impugnada pela Fazenda Pública

II - avaliação cadastral;

III - valor locativo, real ou arbitrado.

Parágrafo único. Na determinação da base d: cálculo não se considera o valor dos bens móveis mantidos, em caráter permanente ou temporário, no imóvel, para efeito de sua utilização, exploração, embelezamento ou comodidade.

Art. 35. Contribuinte do impôsto é o proprietátio do imóvel, ou o titular do seu dominio útil, ou o seu possuidor a iusto tituio.

\section{Seção III - Impôsto sôbre a Transmissão de Bens Imóveis e de Direitos a êles Relativos}

Art. 36. O impôsto, de competência dos Estados, sôbre a transmissão de bens imóveis e de direitos a êles relativos, tem como fato gerador:

I - a transmissão, a qualquer título, da propriedade ou do dominio útil de bens imóveis por natureza ou por acessão fisica, como definidos em lei;

II - a transmissão, a qualquer título, de direitos reais sôbre imóveis, exceto os direitos reais de garantia;

III - a cessão de direitos relativos às transmissões referidas nos incisos I e II.

Art. 37. O impôsto não incide sôbre a transmissão dos bens ou direitos referidos no artigo anterior, para sua incorporação ao capital de pessoas jurídicas, salvo o daquelas cuja atividade preponderante seja a venda ou a locação da propriedade imobiliária ou a cessão de direitos relativos à sua aquisiç̧̃̃o.

$\S 1^{2}$ Considera-se caracterizada a atividade preponderante referida neste artigo quando se verifique qualquer das seguintes hipóteses:

I - os bens ou direitos transmitidos permaneçam no ativo imobilizado da pessoa jurídica adquirente por prazo inferior a 2 (dois) anos:

II - a receita bruta da pessoa jurídica adquirente seja composta, nos 2 (dois) anos anteriores e nos 2 (dois) subseqüentes à aquisição, em mais de $50 \%$ (cinqüenta por cento) por resultados oriundos das operaçốes a que se refere êste artigo.

$\S 2^{\circ}$ Verificada a ocorrência de qualquer das hipóteses previstas no parágrafo anterior, tornar-se-á devido o impôsto nos têrmos da lei vigente à data da aquisição. 
$\S 3^{\circ} \mathrm{O}$ disposto no parágrafo anterior não se aplica à transmissão dos bens ou direitos, adquiridos na forma dêste artigo, quando realizada em conjunto com a totalidade do patrimônio da pessóa jurídica alienante.

Art. 38. A base de cálculo do impôsto é:

I - nas transmissões por ato entre vivos, a titulo oneroso ou gratuito, o valor dos bens ou direitos transmitidos;

II - nas transmissões causa mortis, o valor dos bens ou direitos trans. mitidos, que se contenham no quinhão de cada herdeiro ou legatário.

$\S 1$ ? $\mathrm{O}$ valor a que se refere êste artigo é determinado por avaliação contraditória, na forma reguladà em lei.

$\S 2^{\circ}$ Nas transmissões por ato entre vivos, a lei pode determinar que o impôsto seja cobrado, por antecipação, na base do preço ou do valor declarado pelas partes, imputando-se o respectivo montante sôbre o devido na base da avaliação a que se refere o parágrafo anterior.

$\S 3^{\circ} \mathrm{Na}$ hipótese prevista no parágrafo anterior, o direito de iniciar o procedimento de avaliação contraditória extingue-se no prazo de um ano, contado da data do recolhimento do impôsto por antecipação.

$\S 4^{\circ}$ O impôsto pago na cessão de direitos, a que se refere o inciso III do art. 36, deduz-se do impôsto devido na ulterior transmissâo entre as mesmas partes.

Art. 39. A aliquota do impôsto não excederá os limites fixados em resolução do Senado Federal, que distinguirá:

I - nas transmissões por ato entre vivos, para efeito de aplicação de aliquota mais baixa, os casos:

a) em que o adquirente a título oneroso seja o cessionário de direitos cuja cessão tenha sido tributada nos têrmos do inciso III do art. 36;

b) em que o adquirente a titulo gratuito seja herdeiro sucessivel do transmitente;

c) que atendam à politica habitacional da União;

II - nas transmissões causa mortis, segundo o grau de parentesco, ou a ausência de parentesco, entre o transmitente, o herdeiro ou legatário.

Art. 40. O montante do impôsto é dedutivel do devido à União, a título do impôsto de que trata o art. 43, sôbre o provento decorrente da miesma transmissão.

Art. 41. O impôsto compete ao Estado da situação do imóvel transmitido, ou sôbre o qual versarem os direitos cedidos, mesmo que a mutação patrimonial decorra de sucessão aberta no estrangeiro.

Art. 42. Contribuinte do impôsto é o adquirente dos bens oư direitos transmitidos.

\section{Seção IV - Impôsto sôbre a Renda e Proventos de Qualquer Natureza}

Art. 43. O impôsto, de competência da União, sôbre a renda e proventos de qualquer natureza, tem como fato gerador a aquisição da disponibilidade, econômica ou juridica, de acréscimo patrimonial a título oneroso ou gratuito.

Art. 44. A base de cálculo do impôsto é, na forma do disposto em lei, o montante, real ou presumido, do acréscimo patrimonial tributável, ou parte dêle, com as deduções e abatimentos nela previstos.

Art. 45. Contribuinte do impôsto é o titular da disponibilidade a que se refere o art. 43 , sem prejuizo de atribuir a lei essa qualidade: 
I - à fonte pagadora do acréscimo patrimonial, quando o titular da respectiva disponibilidade não seja identificado, ou seja domiciliado ou residente no estrangeiro;

II - ao possuidor dos bens produtores do acréscimo patrimonial.

\section{CAPITULO IV}

\section{IMPOSTOS SOBRE A PRODUÇÃO E A CIRCULAÇÃO}

\section{Seção I - Impôsto sôbre Produtos Industrializados}

Art. 46. O impôsto, de competência da União, sôbre produtos industrializados tem como fato gerador:

I - o seu desembaraço aduaneiro, quando de r.rocedência estrangeira;

II - a sua saída dos estabelecimentos a que se refere o parágrafo único do art. 50; leilão.

III - a sua arrematação, quando apreendido ou abandonado e levado a

Parágrafo único. Para os efeitos dêste impôsto, considera-se industrializado o produto que tenha sido submetido a tualquer operação que the modifique a natureza ou a finalidade, ou o aperfeiçoe para o consumo.

Art. 47. A base de cálculo do impôsto é:

I - no caso do inciso I do artigo anterior, o preço normal, como definido no inciso II do art. 20, combinado com o art. 21 e seu parágrafo único, acrescido do montante do impôsto sôbre a importação, das taxas exigidas para entrada do produto no país, e dos encargos cambiais, efetivamente pagos pelo importador, ou dêle exigiveis;

II - no caso do inciso II do artigo anterior:

a) quando a saida decorrer de operação a titulo oneroso, o respectivo preço ou valor, inclusive tôdas as despesas acessórias debitadas ao destinatário ou adquirente, salvo as excluidas por lei, e desprezados os descontos ou abatimentos condicionais;

b) nas demais hipóteses, o preço normal que o produto, ou seu similar, atingiria, no mercado atacadista da praça do remetente, em uma venda como definida no art. 21 e seu parágrafo único, acrescido das despesas acessórias a que se refere a alinea anterior;

III - no caso do inciso III do artigo anterior, o preço da arrematação.

Art. 48. O impôsto é seletivo em função da essencialidade dos produtos,

Art. 49. O impôsto é não-cumulativo, abatendo-se, em cada operação, o montante cobrado nas anteriores.

Parágrafo único. Para os efeitos dêste artiggo, a lei disporá por forma a que o impôsto devido resulte da diferença a maior, em determinado frciodo. entre o montante total do impôsto relativo aos produtos saidos de um mesmo estabelecimento do contribuinte, e o montante total do impôsto relativo aos produtos nêle entrados.

Art. 50. Contribuinte do impôsto é:

I - o importador, como definido no inciso I do art. 23 , de produtos estrangeiros, ou quem a lei a êle equiparar;

II - o produtor, assim entendido aquêle que pratique a industrialização, como definida no parágrafo único do art. 46 , de produtos nacionais, ou quem a lei a êle equiparar; 
III - o comerciante de produtos sujeitos ao impösto, que os forneça aos contribuintes definidos no inciso anterior; leilão.

IV - o arrematante de produtos apreendidos ou abandonados, lev'ados a

Parágrafo único. Para os efeitos dêste impôsto, considera-se contribuinte autônomo qualquer estabelecimento de importador, produtor, comerciante ou arrematante.

\section{Seção II - Impôsto Estadual sôbre Operações Relativas à Circulação de Mercadorias}

Art. 51. O impôsto, de competência dos Estados, sôlbre operações relativas à circulação de mercadorias, tem como fato gerador:

I - a saida da mercadoria de estabelecimento comercial, industrial ou produtor;

II - a transmissão, a título oneroso ou gratuito, por comerciante, industrial ou produtor, da propriedade de mercadoria, ou de titulo que a represente, na forma da lei aplicável, ainda que sem saida ou movimentação física da mercadoria.

§ 1. O impôsto não incide sôbre a venda a varejo, diretamente a consumidor, de gêneros de primeira necessidade, definidos como tais por ato do Poder Executivo Estadual.

$\S 22^{\circ}$ Para os efeitos dêste artigo não são considerados mercadorias os bens imóveis que constituem ativo fixo do titular de estabelecimento comercial, industrial, ou produtor.

$\S 3^{\circ} \mathrm{O}$ impôsto compete ao Estado em cujo território se encontre a mercadoria à data da ocorrência de qualquer dos fatos previstos nos incisos I e II dêste artigo.

§ 4. A incidência sôbre a transmissão de titulo representativo de mercadoria exclui a incidência sôbre a ulterior saida, dela decor:ente, da própria mercadoria.

Art. 52. A base de cálculo do impôsto é:

I - na saída de mercadoria, ou na transmissão da sua propriedade, a título oneroso, o preço ou o valor da operação de que decorrem, como definidos no inciso II do art. 20, combinado com o art. 21 e seu parágrafo único, desprezados os descontos ou abatimentos condicionais e acrescido de tôdas as despesas acessórias debitadas ao destinatário ou adquirente, salvo as de transporte e seguro;

II - no fornecimento de mercadorias juntamente com a prestação de serviços a usuários ou consumidores finais, o preço da aquisição, pelo contribuinte, das mercadorias fornecidas, acrescido de $30 \%$ (trinta por cento) no caso de construtores e empreiteiros de obras, ou de $50 \%$ (cinqüenta por cento) nos casos de oficinas de consêrto, reparo e restauração, e de furnecimento de refeições ou bebidas em hotéis, restaurantes e estabelecimentos similares;

III - na saida de mercadoria para o exterior, o preço ou o v'alor da operação de que decorra, incluidas tôdas as despesas verificadas até a colocação d’a mercadoria no pôrto de embarque ou no local da saida do território nacional;

IV - nos demais casos, o preço normal que a mercadoria, ou mercadoria similar alcançaria no mercado atacadista da praça do remetente ou transmitente, obedecido o disposto no inciso I e no $\$ 2^{\circ}$ dêste artigo.

$\S 1^{2}$ Na saida de mercadoria de estabelecimento produtor, exceto quando decorrente de operação direta para fora do Estado, a base de cálculo será 
igual a $50 \%$ (cinqüenta por cento) dos valôres a que se referem os incisos I ou IV.

§ 2. $\mathrm{Na}$ transferência de mercadorias para estabelecimento ou tcpresentante do contribuinte em outro Estado, a base de cálculo definida no inciso IV não excederá o preço normal de venda daqueles, abatido de $20 \%$ (vinte por cento) nas vendas por atacado, ou de 30\% (trinta por cento) nas vendas a varejo, e deduzidas, ainda, as despesas de transporte e seguro.

$\S 3^{\circ}$ Nas operações sujeitas ao impôsto a que se refere o art. 46, o respectivo montante não integra a blase de cálculo dêste impôsto.

Art. 53. O impôsto é não-cumulativo, abatendo-se, em cada operação, o montante cobrado nas anteriores, pelo mesmo ou por outro Estado.

$\S 1^{\circ}$ Para os efeitos dêste artigo, a lei disporá por forma que o impôsto devido resulte da diferença a maior, em determinado periodo, entre o montante total do impôsto relativo às mercadorias saidas de um mesmo estabelecimento do contribuinte, e o montante total do impôsto relativo às mercadorias nêle entradas.

§ 2. Em substituição ao sistema de que trata o parágrafo anterior, poderá a lei dispor que o impôsto devido resulte de diferenç̧ a maior entre o montante do impôsto relativo à operação a tributar" e o devido, pelo mismo cu por outro contribuinte, na incidência anterior sôbre a mesma mercadoria.

Art. 54. A aliquota do impôsto é uniforme para tôdas as mercadorias. não excedendo, nas saidas de mercadorias decorrentes de operação que as destinem a outro Estado, o limite fixado em resolução do Senado Federal.

parágrafo único. Quando a aliquota fixada na lei de tm Estado fôr superior ao limite a que se refere êste artigo, prevalecerá aquêle limite como aliquota aplicável nas saidas para outro Estado.

Art. 55. Contribuinte do impôsto é o comerciante, industrial ou pro. dutor, que promove a saida da mercadoria ou lhe transmita a propriedade.

$\S 1^{\text {p }}$ Para os efeitos dêste impôsto, considera-se produtor qualquer pessoa que se dedique à produção agrícola, pecuária ou extrativa, em estado natural ou submetida a processo elementar de beneficiamento.

$\S 2$. A lei pode atribuir a qualidade de contribuinte substituto:

I - ao comerciante ou industrial destinatário ou adquirente, quando a saida ou transmissão da propriedade da mercadoria seja realizada pelo produtor;

II - ao industrial ou comerciante atacadista, com relação à revenda de mercadoria dêle adquirida por comerciante varejista.

$\S 3^{\circ}$ Fara os efeitos dêste impôsto, considera-se cuntribuinte autônomo qualquer estabelecimento de produtor, industrial, ou comerciante.

\section{Seção III - Impôsto Municipal sôbre Operaçốes Relativas à Circulação de Mercadorias}

Art. 56. O Município poderá cobrar o impôsto a que se refere o artigo 51 sôbre operações ocorridas no seu território, assim entendidas:

I - no caso regulado no inciso I do art. 51, aquelas em que o estabelecimento remetente da mercadoria seja situado no território do Município;

II - nos casos regulados no inciso II do art. 51 , as relativas a mercadorias que se encontram no território do Municipio à data cla transmissăo de sua propriedade ou do titulo que a represente. 
Art. 57. A lei disporá por forma que o impôsto devido resulte, alternativamente:

I - da aplicação, ao montante devido ao Estado, a titulo do impôsto de que trata o art. 51 , de aliquota não superior a $30 \%$ (trinta por cento);

II - da aplicação, à base de cálculo, definida nos incisos I ou II do art. 52 , e seus $\$ \S 1$ e $2^{\circ}$, de aliquota não superior a $30 \%$ (trinta por cento) da instituída pelo Estado, observado o disposto nos arts. 53 e 54 .

Art. 58. E assegurada ao Municipio a cobrança do impôsto relativo a operações ocorridas em seu território, quando da lei estadual resulte supressão ou diferimento da incidência do impôsto de que trata o art. 51 .

Art. 59. O Municipio observará a legislação estadual relativa ao im. pôsto de que trata o art. 51 , podendo a respectiva fiscalização ter acesso aos livros e demais documentos fiscais nela previstos, mas não poderá impor aos contribuintes obrigações acessórias, salvo nos casos en que a cobrança do impôsto the é assegurada pelo artigo anterior.

Parágrafo único. Nas hipóteses previstas no artigo anterior, o Municipio cobrará o impôsto com base na lei estadual, como se a operação fôsse tributada pelo Estado.

\section{Seşão IV - Impôsto sôbre Operações de Crédito, Câmbio e Seguro e sôbre Operações Relativas a Titulos e Valôtes Mobiliários}

Art. 60. O impôsto, de competência da União, sôbre operações de crédito, câmbio e seguro, e sôbre operações relativas a tituios e valôres mobiliários, tem como fato gerador:

I - quanto às operações de crédito, a sua efetivação pela entrega do montante ou do valor que constitua o objeto da obrigação, ou sua colocação à disposição do interessado;

II - quanto às operações de câmbio, a sua efetivação pela entrega de moeda nacional ou estrangeira, ou de documento que a represente, ou sua rolocação à disposição do interessado, em montantes equivalentes à moeda estrangeira ou nacional entregue ou posta à disposição por êste;

III - quanto às operações de seguro, a sua efetivação pela emissão da apólice ou do documento equivalente, na forma da lei aplicável;

IV - quanto às operações relativas a titulo e valôres mobiliários, a emissão, transmissão, pagamento ou resgate dêstes, na forma da lei aplicável.

$\$ 1^{\circ}$ A incidência definida no inciso I exclui a definida no inciso IV, e reciprocamente, quanto à emissão, ao pagamento, ou ao resgate do titulo representativo de uma mesma operação de crédito.

\$ 2. Para os efeitos do inciso IV, consideram-se títulos de crédito os titulos representativos de mercadoria, quando emitidos, transmitidos, pagos, ou resgatados por quem não seja comerciante, industrial, ou produtor.

Art. 61. A base de câlculo do impôsto é:

I - quanto às operações de crédito, o montante da obrigação, compre. endendo o principal e os juros;

II - quanto às operações de câmbio, o respectivo montante em moeda nacional, recebido, entregue, ou pôsto à disposição:

III - quanto às operações de seguro, o montante do prêmio;

IV - quanto às operações relativas a titulos e valôres mobiliários;

a) na emissão, o valor nominal mais o ágio, se houver; 
b) na transmissão, o preço, ou o valor nominal, ou o valor da cotação em Bôlsa, como determinar a lei;

c) no pagamento ou resgate, o preço.

$\S 1^{\circ}$ Integram a base de cálculo as comissões e demais despesas acessórias, percebidas por quem seja parte nas operações tributadas quando não configurem remuneração de serviço prestado por terceiro.

$\S 2^{\circ}$ O Poder Executivo pode, nas condições e nos limites estabelecidos em lei, alterar as aliquotas ou as bases de cálculo do impôsto, a fim de ajus. tá-lo aos objetivos da politica monetária.

Art. 62. Contribuinte do impôsto é qualquer das fartes na operação tributada, conforme dispuser a lei.

Art. 63. A receiláa liquida do impôsto destina-se à formação de reservas monetárias, na forma da lei.

\section{Seção $V$ - Impôsto sôbre Serviços de Transportes e Comunicąóes}

Art. 64. O impôsto, de competência da União, sôbre serviçus de transportes e comunicaçǒes tem como fato gerador:

I - a prestação do serviço de transportes de pessoas, bens, mercadorias, ou valôres, por via terrestre, marítima, fluvial, lacustre, ou aérea, salvo quando o traieto se contenha inteiramente no território de um mesmo Municipio,

II - a prestação de serviços de comunicação, assim entendida a transmissão e o recebimento de mensagens escritas, falsas ou visuais, por qualquer processo manual, mecânico, elétrico ou eletrônico, salvo quando os pontos de emissão e de recebimento situem-se no território de um mesmo Município e a mensagem em curso não possa ser captada fora dêsse território.

Art. 65. A base de cálculo do impôsto é o preço do servişo, acrescido das despesas acessórias cobradas do usuário.

Art. 66. Contribuinte do impôsto é o prestador do serviço.

\section{Seção VI - Impôsto sôbre serviços de qualquer naturera}

Art. 67. O impôsto, de competência dos Municípios, sôbre serviços de qualquer natureza, tem como fato gerador a prestaçăo, por emprêsa ou profissional autônomo, com ou sem estabelecimento fixo, de serviço que não configure, por si só, fato gerador de impôsto de competência da União ou dos Estados.

Art. 68. A base de cálculo do impôsto é a receita liruta proveniente da prestação do serviço, salvo:

I - quando o contribuinte seja pessoa física, em cujo caso o impôsto será cobrado por aliquota fixa, diferenciada em função da natureza do serviço e combinada com o valor locativo do estabelecimento, sua localizaçáo, o valor das instalações permanentes, e outros fatôres pertinentes, determinados em lei, desde que não façam recair o impôsto sôbre a receita bruta real ou presumida;

II - quando a prestação do serviço tenha como parte integrante operação sujeita ao impôsto de que trata o art. 51 , em cujo caso êste impôsto será calculado sôbre a receita bruta decorrente da aludida prestaçáo no periodo considerado, menos o preço ou valor a que se refere o inciso II do art. 52 .

Art. 69. Contribuinte do impôsto é cada estabelecimento, ainda que sem personalidade jurídica própria, do prestador do serviço. 


\section{CAPÍTULO V}

\section{IMPOSTOS ESPECIAIS}

Seção I - Impôsto sôbre operações relativas a combustiveis, lubrificantes, energia elétrica e minerais do Pais

Art. 70. O impôsto de competência da União, sōbre operaçòes relativas a combustiveis, lubrificantes, energia elétrica e minerais do pais, tem como fato gerador:

I - a produção, como definida no art. 46 e seu parágrafo único;

II - a importação, como definida no art. 19;

III - a circulação, como definida no art. 51;

IV - a distribuição, assim entendida a colocação do produto no estabelecimento consumidor ou em pôsto de venda ao público;

$\mathrm{V}$ - o consumo, assim entendida a venda do produto so público.

$\S 1^{\circ}$ Para os efeitos dêste impôsto, a energia elétrica considera-se prociuto industrializado.

$\S 2^{\circ}$ O impôsto incide, uma só vez, sôbre uma das operações previstas em cada inciso dêste artigo, como dispuser a lei, e exclui quaisquer outros tributos, sejam quais forem sua natureza ou competência, incidentes sôbre aquelas operações;

Art. 71. A lei observará o disposto neste Código:

I - relativamente ao impôsto sôbe produtos industrializados, quando a incidência seja sôbre a produção ou sôbre o consumo;

II - relativamente ao impôsto sôbre a importação, quando a incidência seja sôbre essa operação;

III - relativamente co impôsto sôbre operações relativas à circulaşão de nuercadorias, quando a incidência seja sôbre a distribuição.

\section{Seção II - Impostos Extraordinázios}

Art. 72. Na iminência ou no caso de guerra externa, a União pode instituir, temporàriamente, impostos extraordinários, compreendidos ou não entre os referidos neste Código, suprimidos, gradativamente, no prazo máximo de cinco anos, contados da celebração da paz.

TÍTULO IV

\section{TAXAS}

Art. 73. As tax'as cobradas pela União, pelos Estados, pelo Distrito Federal, ou pelos municipios, no âmbito de suas respectivas atribuições, têm como fato gerador o exercicio regular do poder de policia, ou a utilização, efetiva ou potencial, de serviço público especifico e divisivel, prestado ao contribuinte ou pôsto à sua disposição.

Parágrafo único. A taxa não pode ter base de cálculo ou fato gerador idênticos aos que correspondam a impôsto.

Art. 74. Considera-se poder de polícia a atividade da administração pública que, limitando ou disciplinando direito, interêsse, oı liberdade, regula a prática de ato ou a abstenção de fato, em razão de interêsse público concernente à segurança, à higiene, à ordem, aos costumes, à tranqüilidade pública, ou ao respeito à propriedade e aos direitos individuais o:1 coletivos. 
Parágrafo único. Considera-se regular o exercício do poder de policia quando desempenhado pelo órgão competente, nos limites da lei aplicável, com observância do processo legal e, tratando-se de atividade que a lei tenha como discricionário sem abuso ou desvio de poder.

Art. 75. Os serviços públicos a que se refere o art. 73 consideram-se:

I - utilizados pelo contribuinte:

a) efetivamente, quando por êle usufruidos a qualquer título;

b) potencialmente, quando, sendo de utilização compulsória, sejam postos à sua disposição mediante atividade administrativa $\mathrm{em}$ efetivo funcionamento;

II - especifico, quando possam ser destacados em unidades autônomas de intervenção, de utilidade, ou de necessidades públicas;

III - divisiveis, quando suscetiveis de utilizaçào, suporadamente, por parte de cada um dos seus usuários.

Art. 76. Para efeito da instituição e cobrança de taxas, consideram-se compreendidas no âmbito das atribuições da União, dos Estados, do Distrito Federal, ou dos Municipios, aquelas que, segundo a Constituição Federal, as Constituições dos Estados, as Leis Orgânicas do Distrito Federal e dos Municipios, e a legislação com elas compativeis, competem a cada uma dessas pessoas de direito público.

\section{TíTuLO $\mathrm{V}$}

\section{CONTRIBUIÇAO DE MELHORIA}

Art. 77. A contribuição de melhoria, cobrada pela União, pelos Estados, pelo Distrito Federal, ou pelos Municipios, no âmbito de su.is respectivas atribuições, é instituida para fazer face ao custo de obras públicas de que decorra valorização imobiliária, tendo como limite total a aespesa realizada. e como limite individual o acréscimo de valor que da obra resultar para cada inóvel beneficiado.

Art. 78. A lei relativa à contribuição de melhoria observará os seguintes requisitos minimos:

I - Publicação prévia dos seguintes elementos:

a) memorial descritivo do projeto;

b) orçamento do custo da obra;

c) determinação da parcela do custo da obra a ser inanciada pela contribuição;

d) delimitação da zona beneficiada e identificação de càda um dos imóveis nela situados;

e) cálculo da distribuição do beneficio $e$, se aquela não fôr homogênea em tôda a zona, determinação dos graus relativos de valorização em cada uma das áreas diferenciadas, nela contidas;

f) determinação do fator individual de absorção do beneficio por farte de cada um dos imóveis a que se refere a alinea " $\mathrm{d}$ ", com base na sua localização, na superficie do seu terreno, na sua área construida. na dimencão linear da sua testada, no seu valor venal, nas condições de sua utılização ou exploração, ou na combinação de quaisquer dêsses elementos;

g) cálculo do montante da contribuição relativa a cada imóvel, determinada pelo rateio da parcela do custo da obra, a que se refere a alinea " $c$ ", pelos imóveis situados na zona beneficiada, em funçcio do fator individial atribuido a cada um dêles na forma da alinea anterior;

II - Fixação de prazo, não inferior a 30 dias, para impugnação de qualquer dos elementos referidos no inciso anterior, por qualquer dos interessados ou por entidade que os represente; 
III - regulamentação do processo administrativo de îstruçăo e julgamento da impugnação a que se refere o inciso anterior, sem prejuizc da sua apreciação judicial.

\section{TítuLo VI}

\section{DISTRIBUIÇÕES DE RECEITAS TRIBUTTÁRIAS}

\section{Art. 79. Serão distribuídos pela União:}

I - aos Municipios da localização dos imóveis, o produto da arrecadação do impôsto a que se refere o art. 30;

II - aos Estados e aos Municipios, o produto da arrecadação, na fonte, do impôsto a que se refere o art. 43, incidente sôbre a renda das obrigações de sua divida pública e sôbre os proventos dos seus servidores e dos de suas autarquias.

Parágrafo único. As autoridades arrecadadoras dos tributos a que se refere êste artigo farão entrega aos Estados e Municipios das importâncias recebidas correspondentes a êstes impostos à medida em que forem sendo arrecadadas, independentemente da ordem das autoridades superiores, em prazo não maior de 30 (trinta) dias, a contar da data do recolhimento dos mesmos t $t$ ibutos, sob pena de demissão.

Art. 80. Do produto da arrecadação dos impostos a que se referem o art. 43 e o art. $46,80 \%$ (oitenta por cento) constituem receita da União e o restante distribuir-se-á à razão de $10 \%$ (dez por cento) ao Fundo de Participação dos Estados e do Distrito Federal, e 10\% (dez por cento) ao Funco de Participação dos Municipios.

$\S 1^{\circ}$ Do total recebido nos têrmos do parágrafo anterior, cada entidade participante destinará obrigatòriamente $50 \%$ (cinqüienta por cento), pelo menos, ao seu orçamento de capital.

$\S 2^{8}$ Para os efeitos de cálculo da percentagem destinada aos Fundos de Participação, exclui-se do produto da arrecadação do impôsto a que se refere o art. 43 a parcela distribuida nos têrmos do inciso II do art. 79.

Art. 81. Sem prejuizo do disposto no artigo anterior, os Estados e Municipios que celebrem com a União convênios destinados a assegturar ampla e eficiente coordenação dos respectivos programas de investimentos a serviços públicos, especialmente no campo da politica tributária, poderão participar de até $10 \%$ (dez por cento) da arrecadação efetuada, nos respectivos territórios, proveniente do impôsto referido no art. 43 , incidente sôbre o rendimento das pessoas fisicas, e no art. 46, excluido o incidente sôbre o fumo c bebidas alcoólicas.

Art. 82. Do produto da arrecadação do impôsto a que se refere o art. 70 serão distribuidos aos Estados, ao Distrito Federal e aos Municipios 60\% (sessenta por cento) do que incidir sôbre operações relativas a combustiveis, lubrificantes e energia elétrica, e $90 \%$ (noventa por cento) do que incidir sôbre operações relativas a minerais do país.

Art. 83. As distribuições de receitas, a que aludem os arts. 80 e 82 , serão reguladas em lei complementar especial.

Art. 84. A lei federal pode cometer aos Estados, ao Distrito Federal, ou aos Municipios o encargo de arrecadar os impostos, de competência da União, cujo produto lhes seja distribuido no todo ou em parte.

Parágrafo único. O disposto neste artigo aplica-se à srrecadaçä́o dos impostos de competência dos Estados, cujo produto êstes venham a distribuir, no todo ou em parte, aos respectivos Municípios.

Nota - Redação preliminar, aprovada em 10-5-66. 


\section{FUNDO DE PARTICIPAÇÃO DOS ESTADOS}

Art. ... O Fundo de Participação dos Estados será distribuído proporcionalmente à população e ao inverso da renda per capita de cada Estado, de conformidade com o disposto neste Capitulo.

Parágrafo único. Para os efeitos desta lei, o Distrito Federal será considerado como Estado.

Art. ... O coeficiente de participação de cada Estado será obtido multiplicando-se o fator representativo da população ( $\mathrm{Fa}$ tor P) pelo fator representativo do inverso da renda per capita (Fator R).

Art. ... O fator representativo da população (Fator P) será estabelecido com base na percentagem da população de cada Estado em relação ao total do país, obedecido o seguinte escalonamento:

Estados

I - Estados com populaçăo repreß̌entando até $2 \%$ da população do pais $\ldots \ldots \ldots \ldots \ldots \ldots$.

Fator $P$

I - Idem, acima de 2 até $5 \%$ :

a) Pelos primeiros $2 \% \ldots \ldots \ldots \ldots \ldots$.

b) Pelo excedente, cada $0,3 \%$, ou fração. mais

III -- Idem, acima de 5\%:

a) Pelos primeiros $5 \% \ldots \ldots \ldots \ldots \ldots \ldots$

b) Pelo excedente, até um máximo de $10 \%$. cada $0,5 \%$, ou fração, mais

Parágrafo único. Para os efeitos dêste artigo, tomar-se-ão os dados relativos a população estimada pelo I.B.G.E. para o penúltimo exercício anterior àquele em que são devidas as quctas estaduais.

Art. ... O fator representativo da renda per capita (Fator R) será estabelecido em função do inverso do indice relativo à renda per capita de cada Estado, tomando-se como 100 a renda média do pais, obedecido o seguinte escalonamento:

INVERSO DO INDICE RELATIVO A RENDA

"Per capita" de cada Estado

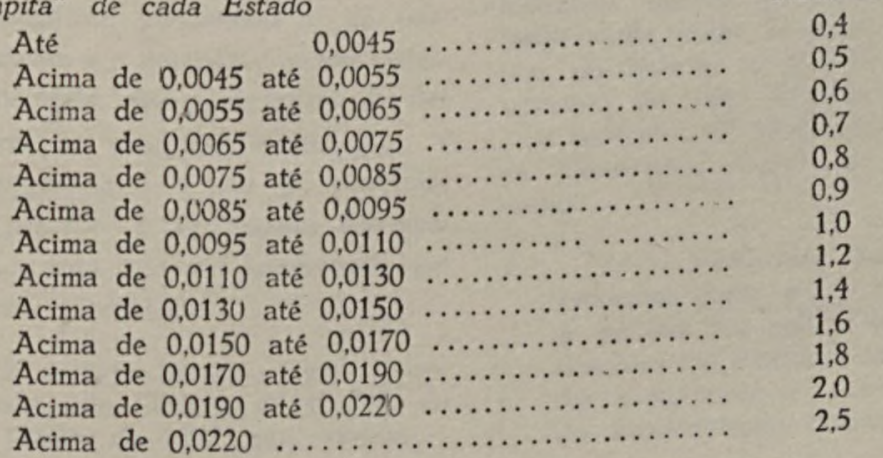


Parágrafo único. Para os efeitos dêste artigo, tomar-se-á por base a renda per capita relativa ao últımo ano para o qual existam estimativas efetuadas pela Fundação Getúlio Vargas.

Art. ... Obtidos, na forma dos artigos anteriores, os coeficientes de participação de todos os Estados serão os mesmos, para facilidade de cálculo, convertidos em percentagens sôbre o o total do Fundo. 